\section{E-LOGOS}

ELECTRONIC JOURNAL FOR PHILOSOPHY ISSN 1211-0442

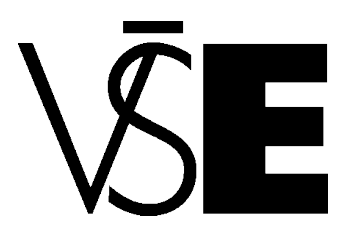

University of Economics

Prague

\title{
Plagiát - selhání jednotlivce či přirozený produkt systému?
}

Emanuel Hurych

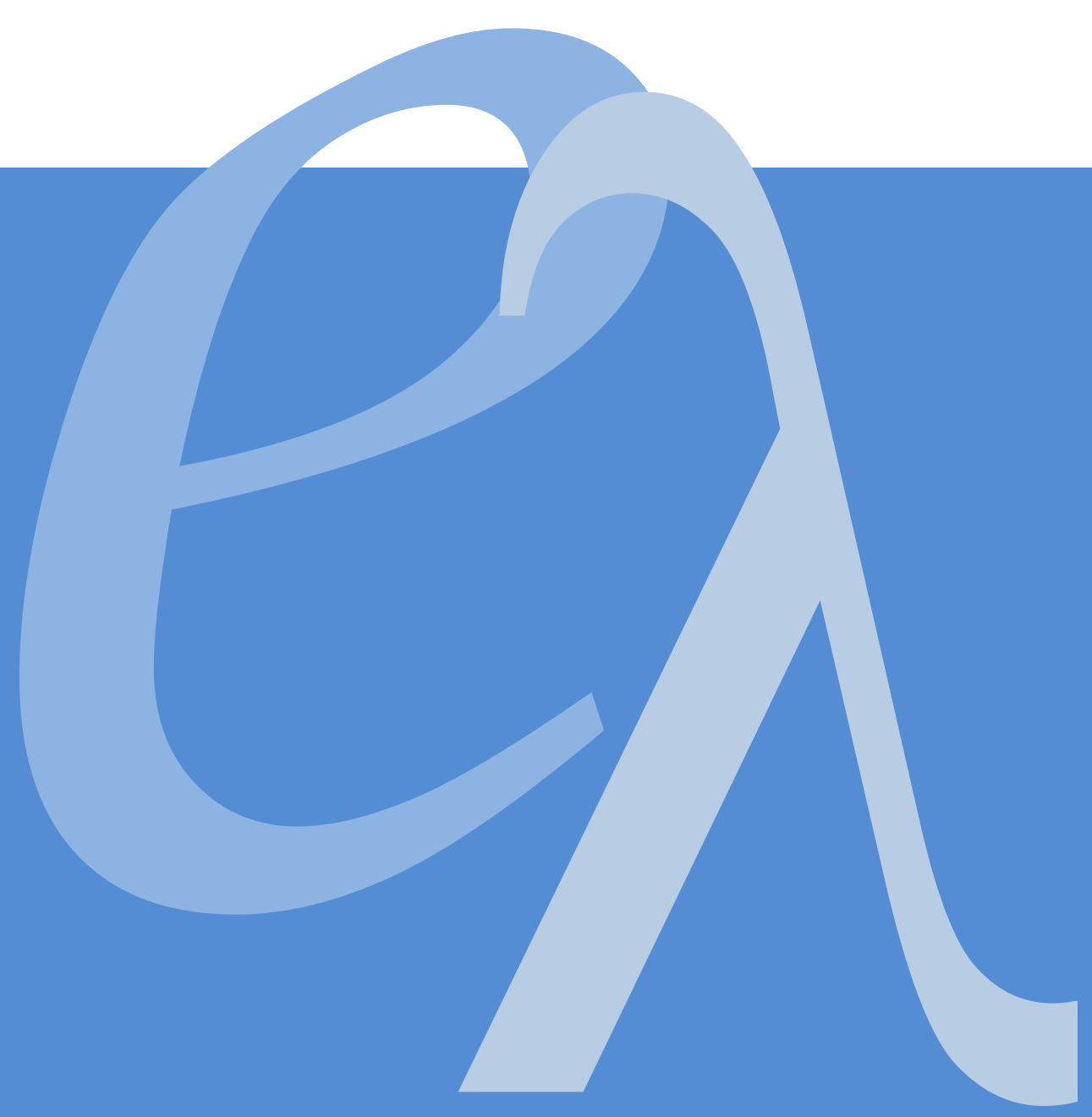




\begin{abstract}
This article is devoted to the topic of plagiaries, especially connected with scientific research. The question about the roots of this negative phenomenon in the contemporary society is asked within it. The purposes are connected with personal ambitions of a concrete person and his/her moral qualities undoubtedly. However, the author argues that the complex of factors, which arise from the social conditions, influence occurrence of plagiarism. Some of the social factors even support its appearance. The key message of the text is based on the idea that the conception of research and its evaluation should support meaningful writing and try to decrease formalism in this field. Then plagiarism would be rejected not just de jure but also de facto.
\end{abstract}

Keywords: plagiary, individual aspects, social aspects, morality, ethics

\begin{abstract}
Abstrakt
Článek je věnován tématu plagiátorství, zejména v oblasti vědeckého výzkumu. Vznáší otázku, jaké jsou kořeny tohoto negativního jevu. Příčiny mohou být v ambicích každého jedince a souvisejí s jeho morálními kvalitami. Kromě toho autor však hovoří o komplexu faktorů, které vyrůstají ze sociálního prostředí a ovlivňují výskyt plagiátorství $\mathrm{v}$ současné společnosti. Některé z těchto faktorů jej přímo podporují. Hlavní myšlenkou textu je, že systém hodnocení vědeckého výzkumu by měl dbát o smysluplnost textů a snížení formalismu. Pak by plagiátorství nebylo odmítáno pouze de iure, ale také de facto.
\end{abstract}

Klíčová slova: plagiát, individuální aspekty, společenské aspekty, morálka, etika 


\section{Úvod a východiska}

Tento text je věnován tématu plagiátu a spolu s ním i otázce, zda přičiny plagiátorství jsou pouze záležitostí osobních ambicí jednotlivce a jeho morálních kvalit, či zda se jedná o složitější komplex faktorů, z nichž některé vycházejí ze společenského prostředí. Plagiátem obecně rozumíme dílo, jež je (v různých podobách a v různé míře) napodobeninou díla jiného, avšak autor jej vydává za dílo vlastní. Historie plagiátorských počinů v literatuře je předlouhá, v poslední době se ovšem téma plagiátů stalo $\mathrm{v}$ tuzemském prostředí vysoce aktuálním zejména vinou neoprávněně získaných titulů a neprávem obhájených vědeckých prací. Podstata plagiátorství se přsesunem z pole fikce do vědeckého prostředí sice nemění, avšak nabývá "opticky závažnějších“ společenských dopadů. Je to dáno zřejmě i jakýmsi zostřením kontur. Od „vykrádání“ idejí a nápadů, které je mnohdy problematicky prokazatelné (to ilustrují např́klad komplikované soudní pře o použité hudební motivy), se plagiátoři posunuli k doslovnému opisování celých pasáží, což je v době rozvinutých možností evidence publikovaných textů relativně snadno zjistitelné a vina je dobře prokazatelná.

Etický pohled nám primárně rríká, že plagiátorství není v principu správné. Immanuel Kant, v díle Základy metafyziky mravů hovoří o povinnosti, kdy tento výraz „obsahuje pojem dobré vơle, i když s jistými subjektioními omezeními a překážkami, které však namisto toho, aby jej zakrývaly a činily nezřetelným, jej spiše svou odlišností od sebe vyzvednou a nechají je tím jasněji zazárít." (Kant, 1990, s. 60). Tentýž autor představuje objektivní principy donucující vůli k činnosti coby př́kazy rozumu (imperativy). Tyto imperativy dělí na hypotetické a kategorické. "Zatímco vhypotetických imperativech je předvedena praktická nutnost možného jednání jako prostředku kněčemu jinému, co chceme dosáhnout (či co je možné, abychom chtěli dosáhnout), kategorický imperativ by byl pak ten, který predvádí jednání jako jsoucí samo pro sebe, jako objektivně nutné bez vztahu k jinému účelu." (Kant, 1990, s. 77). Zatímco hypotetický imperativ není možno předjímat, není-li dána podmínka, kategorický imperativ neobsahuje žádnou podmínku. „Kategorický imperativ je tedy pouze jediný, a to tento: jednej jen podle své maximy, od níz můžeš zároveň chtít, aby se stala obecným zákonem." (Kant, 1990, s. 84).

Viděno prizmatem kategorického imperativu je plagiát $\mathrm{v}$ principu stejným morálním pokleskem, jak v oblasti umění (nap̌r. v beletrii), tak pokud jde o vědeckou práci. I ten nejbenevolentnější jedinec připustí, že plagiátorství by se principem obecného zákonodárství stát nemělo. Ovšem na druhé straně, jakými imperativy se ve skutečnosti řídí současná společnost a jak moc jsou kategorické, to jest otázka nejen pro etiky. 


\section{Rovina pravdy a morálky}

Jakkoli je precedens „vypůjčené myšlenky“ starý jako lidstvo samo, současnost přináší nová zadání. Rozsah článku ani jeho zaměření neumožňují širší kritické zhodnocení etických diskursů, proto se pokusíme držet jednoduché linie myšlenek, které téma spíše ilustrují, než by jej vyčerpávajícím způsobem charakterizovaly.

Václav Bělohradský píše v knize Společnost nevolnosti o věku „komunikační hojnosti“, v němž se pokles kulturních hodnot velmi urychlil. „Podobně jako hojnost materiální nepřináší štěstí a mír všem, i komunikační hojnost vyvolává morální krize, konflikty, nerovnost, novou neprůhlednost; především ale hojnost informací paralyzuje schopnost porozumět jim.“ (Bělohradský, 2007, s. 104).

V současné době je velmi obtížné dokládat svou intelektuální vyspělost obecnou dílčí znalostí. Ta je téměř pro každého takřka okamžitě $k$ nalezení na internetu (prostřednictvím připojení přes mobilní telefon je i v terénu získatelná řádově v sekundách). Dostupnost dílčích informací však neznamená, že by se zvýšila úroveň vzdělanosti, nebot' těmto informacím chybí (zákonitě) kontext.

Kde hledat onen kontext, kde hledat souvislosti, jež propojují dílčí hektické, zmatené informace, které na nás naše doba chrlí? Kde najít onen pevný bod, po němž volal Archimedes?

Platon hovoří v dialogu Faidros ústy mnohem racionálněǰśiho Sokrata o hledání pravdy: „A prríčinou onoho velkého usilování uvidět, kde je rovina pravdy, je to, že z tamější louky pochází pastva př́hodná pro nejlepší složku duše a tím že se živí ústroj perutí, kterou je duše nadnášena." (Platon, 1958, s, 29-30).

Rovina pravdy však není snadno definovatelná. Edmund Husserl ve svých Idejích $k$ čisté fenomenologii a fenomenologické filosofii I zpochybňuje existenci „objektivní vědecké pravdy“. Hovoří o praktickém ideálu exaktní eidetické vědy a ideálu matematizace, jako o důležitých postulátech pro "exaktní“ vědy.

„Smysl eidetické vědy vylučuje principiálně jakékoli zahrnutí výsledků poznání empirických věd. Teze skutečnosti, které vystupuji v bezprostředních zjištěních těchto věd, procházeji všemi zprostředkovanými zjištěními. Z faktio vyplývají vždy jen fakta." (Husserl, 2004, s. 32). Vztahy o závislostech mezi eidetickou vědou a vědou o faktech Husserl dále komentuje: „Jestliže je tedy veškerá věda principiálně nezávislá na veškeré vědě o faktech, pak na druhé straně platí opak ohledně vědy o faktech. Neexistuje žádná věda o faktech, která by mohla jako plně rozvinutá věda nezahrnovat eidetické poznatky a být tak nezávislá na eidetických vědách, at už formálních nebo materiálních."

V další kapitole Husserl popisuje empiristický výklad a jeho ztotožnění zkušenosti a originárně dávajícího aktu: „Pravá věda a pravá bezpředsudečnost, jež je této vědě vlastní, vyžaduje jako podklad všech důkazů pouze bezprostředně platné soudy, které 
čerpaji svou svou platnost přmo z originárně dávajicích názorů... Bezprostřední 'viděni", nikoli jen smyslové, zakoušejicí vidění, nýbrž vidění vưbec, jakožto originárně dávajicí vědomí libovolného druhu, je poslední zdrojem oprávnění všech rozumných torzení. Opravňujicí funkci má jen potud, pokud a v jaké míre je originárně dávajicím." (Husserl, 2004, s 49).

Špecián $(2009$, s. 5) interpretuje Husserlovo stanovisko takto: „Vědec se nakonec musí spokojit s pouhým subjektioním a relativním svědectvím individuální zkušenosti, kterým často halasně pohrdá jako pouhým míněním. Veškeré poznání je v konečném důsledku odkázáno na originární danost, s níž se věci ukazuji našim smysli̊m vhorizontu prededvědeckého světa. I vědec jako človèk žije v rámci jeho primárních evidencí. To znamená, že subjektivně relationí dimenze nemůže být prèkonána, ,pravdy o sobě jsou čistě hypotetické."

Patočka (1990, s. 155) na toto téma uvádí: „Husserlova základní myšlenka je, jak shora uvedeno, že filosofie musí být založena nikoli na principech, na obecných pojmech a větách, které zưstávaji vždy hypotézami, byt’ i nezbytnými kvysvětlení jednotlivých skutečností, že musí být založena na ,fenoménech', na tom co se ukazuje, co je př́tomné pro pohled, pro názor. Ale fenoménům stojí v cestě ,náš zpưsob', jak jich ,využíváme' v denní praxi, ve vědách."

Na tuto Patočkovu myšlenku lze navázat otázkou: jak vlastně využíváme fenomény $\mathrm{v}$ denní praxi a jak ve vědách? Jak je to s pravdou a jak s morálkou?

K této otázce se vyjadřuje Nietzsche $(1995, \mathrm{~s} .73)$ v knize Soumrak model:

"Je známo, že požaduji na filosofovi, aby se stavěl ,mimo' dobro a zlo - aby mél ilusi morálního soudu, pod'sebou. Tento požadavek vyplývá z názoru, jenž byl poprvé mnou formulován: ,že vưbec není morálních pravd.' Morální soud má společné se soudem náboženským to, že věř́ ve skutečnosti, jichž není. Morálka je pouze výkladem jistých zjevio, přesněji řěceno ,nesprávným' výkladem."

Je-li morálka nesprávným výkladem jistých jevů, jak tvrdí Nietzsche, a je-li třeba vytvořit nadčlověka, který je př̀konáním člověka a je veden mravními principy, pak je ovšem potřeba především udržet vysoký stupeň nezávislosti jedince na konvencích, zvyklostech a "obecných soudech“, které daná společnost v jistých př́padech chápe jako normy. Pokud nesouhlasíme s tímto výkladem, můžeme mu přesto věnovat určitou pozornost $\mathrm{v}$ kontextu toho, co by dřive vyř̌ceno. $\mathrm{K}$ mravnímu aspektu plagiátu se ještě $v$ tomto textu dostaneme.

\section{Pohyb akceptace}

Nyní se vrátíme zpět k Patočkovi, jehož koncepce tří pohybů lidské existence může posloužit jako jistá platforma pro úvahu o plagiátu a jeho existenci v současné společnosti. Patočka rozeznává tři fundamentální pohyby lidského života. Ty mají svou formu, smysl a časovost. Jedná se o pohyb akceptace, pohyb obrany a pohyb pravdy. 
"Pohyb akceptace spočívá v tom, že do světa musí být člověk prìjat a uveden, že jeho vstup do oblasti otevřeného, individuovaného jsoucna má ráz pripravenosti a a vzájemného skloubení." (Patočka, 1990, s 45). Tento pohyb má podobu zakořeňování či ukotvení. Bednář (2009, s. 28) zmiňuje hédonistickou povahu tohoto pohybu: "Instinkt, afekt a slast jsou zde vưdči komponenty. Je to pohyb, jenž se opírá o malé $i$ velké dějiny a zkušenost (těch druhých, kteři mě 'musí prijímat či alespoň akceptovat)."

Tak jako druzí musí přijímat mou existenci, tak také já v pohybu akceptace přijímám okolní svět. Tento pohyb je celoživotní, svou podstatou pasivní a směřuje k dosažení př́jemna.

Každý autor, postavený před úkol vytvořit dílo, které má být vlastní kreací, je konfrontován s pohybem akceptace minimálně ze dvou možných úhlů pohledu.

Tím prvním je skutečnost, že tvưrčí počin v podobě psaného výstupu je činností čerpající čas a vyžadující určité úsilí. Akceptujeme-li tento svět a nazíráme-li jej hédoinistickým prismatem, nutně se zde skýtá otázka, jakou slast nám provozovaná činnost či její výsledek přináší.

\section{Ukázat mouše cestu ven}

Podle Ludwiga Wittgensteina je úkolem filosofie "ukázat mouše narážející na sklo cestu ven." (Bělohradský, 2007, s. 21). Také autoři rozličných textů marně narážejí do stěn lahve, v níž uvízli a tlučou do zátky, na níž celou svou vahou sedí recenzenti, vydavatelé, komise a komise pro výběr komisí. Ti všichni hledají oporu např́klad právě ve Wittgensteinovi, který tvrdí, že svět je souhrnem faktů, nikoli věcí.

„Vyjádřením faktů je myšlenka coby smysluplný výrok, souhrnem výroků je potom jazyk. Pokud není o něčem možno hovořit, je třeba o tom mlčet. (Blecha, 1996, s. 134). Ve filosofii se hovoří o obratu kjazyku. Jazyková výpověd' je prostředkem, jímž poznáváme vnější svět. Proto musí být přesná a logicky bezchybná, což je nutné "hlídat".

Do prostředí, které ne vždy nabízí a podporuje cestu ven z lahve, jsou mnozí autoři (řečeno s Martinem Heideggerem) „vrženi“ a ne vždy se v něm snadno orientují. Toto není apologie plagiátů, pouze charakteristika podmínek, jež lze (terminologií počítačového věku) označit za „uživatelsky ne vždy vlídné“.

Oproti tomu, pravděpodobně se těžko najde nějaký zainteresovaný jedinec, který by se plagiátorů vědeckých textů zastal. Jedná se o počin všeobecně odsouzeníhodný. Přistižení pisatelé se sice pokoušejí omlouvat své počínání poukazováním na všechny možné průvodní okolnosti, nejčastěji na časový "pres“, ale veškeré výmluvy jsou chabé a těžko mohou obstát. V článku Nedodržování publikační etiky jako výraz „intelektuální lenosti“ se autoři Jirásek a Frömmel pozastavují 
nad případy evidentních plagiátů $\mathrm{v}$ prostředí odborných časopisů v oblasti kinantropologie:

„Pisatel není ochoten strávit dostatečně dlouhou dobu nutným sháněním údajů, jejich promýšlením a zpracováním, ani konečnou jazykovou formulací. Tato nechut' a neochota intelektuálně samostatně pracovat se projeví snahou dojít $k$ obdobnému cíli s vynaložením menšiho úsili, tedy prevzít hotové texty či jejich části a vydávat je za vlastní úvahy a postřehy." (Jirásek a Frömmel, 2005, s. 44-45).

Toto je skutečně situace, kterou je potřeba řešit. Cestou pro vyrovnání se s problémem plagiátů jsou určitě tvrdé postihy a represe, které by měly autory již od podobných úmyslů odradit. Tato cesta je nutná a není důvodu zpochybňovat její správnost. Nicméně, řeší pouze důsledek, nikoli příčinu. A tedy neřeší problém, jak pomoci mouše dostat se ven $z$ lahve.

\section{„Intelektuální lenost“? Ano, ovšem...}

Vrat'me se nyní k termínu „intelektuální lenost“, který byl zmíněn v předchozích odstavcích. Naskýtá se tedy otázka: je smysluplné pátrat po přičinách rostoucí obliby plagiátů v českém prostředí? Vždyt' jejich existence vyplývá ze snahy ulehčit a zjednodušit si práci. Ta je pro lidstvo typická v celém jeho vývoji. Ostatně svým způsobem $\mathrm{k}$ tomuto vývoji vždy vydatně přispívala v podobě vynálezů a technických zdokonalení. Pokud jde o lenost intelektuální, ani ta není výjimkou. „Lenost se stala matkou více filosofi̊ než moudrost," řekl George Bernard Shaw1.

$\mathrm{V}$ př́ípadě plagiátu však není lenost na místě, protože produktem této lenosti je krádež. A krást se nemá, to připustí i zarytý utilitarista. Mohlo by se tedy zdát, že stačí nastavit mantinely, určit pravidla a potom tvrdě vyžadovat jejich splnění. Opisovat je neetické a nesprávné. Hovoříme zde o případech, kdy jedinec vydává obsah původního textu za svůj vlastní. Naprosto neetické (a do očí bijící) je potom přebírat nejen podstatu myšlenek, ale jejich vyjádření ve zcela nezměněné formě.

Tím se dostáváme k rozdělení plagiátorství na úrovni obsahu a formy. Plagiátorství obsahu je záležitostí skutečně prastarou a jeho hranice je složité vymezit. Jak přiznaná ( $v$ tomto případě ovšem nejde o plagiát), tak nepřiznaná inspirace patři například $v$ literatuře či hudbě $\mathrm{k}$ jevům naprosto běžným. Pierre Bayard (2009) ve své knize Le plagiat par anticipation dokonce hovoří o „anticipovaném plagiátorství", tedy o situaci, kdy plagiát předběhl $\mathrm{v}$ čase kopírované dílo. Tato zdánlivě absurdní myšlenka, jež by si jinak zasloužila delší

${ }^{1}$ Citát je natolik frekventovaný a obecně známý, že autor nepovažuje za „intelektuální lenost“, neuvádí-li zde přesný zdroj. 
rozbor, směřuje poněkud mimo podstatu tohoto článku. Je zmíněna pouze jako doklad mnohovrstevnosti pohledů týkajících se plagiátu obsahu.

$\mathrm{V}$ případě plagiátu v kombinaci obsahu a formy, můžeme-li takto označit doslovné (či takřka doslovné) opisy², je situace nepoměrně jednodušší. Jde o případy, kdy jsou zcela a beze změny opsány celé věty a často dokonce odstavce textu. To je zcela průkazné a jde již jen o to, zda k odhalení takovýchto kopírovacích praktik v praxi dojde. Mnozí učitelé, zejména na středních a vysokých školách připisují častost výskytu těchto případů možnosti stahovat informace rychle a bezpracně z internetu. Technické vymoženosti skutečně takovýmto počinům napomáhají. Na druhé straně je na každém učiteli, jak se s danou situací vyrovná, zda požaduje rozbor a vysvětlení textu a zda se nespokojí pouze s jeho odevzdáním. Vlastně se jedná o schopnost přizpůsobení se měnícím podmínkám. V této situaci jsou studenti obecně mírně zvýhodněni. Jednak pouze "plní zakázku“, zatímco učitel ji musí vytvářet a musí definovat podobu výstupu, jakož i způsob jeho hodnocení. K tomu přistupuje skutečnost, že někteří učitelé jsou ve srovnání se studenty limitováni technickou zdatností při práci s počítačem. Mnozí jsou také ovlivněni setrvačností, s níž používají zaběhané formy výuky.

Ovšem, jak uvádí Bělohradský (2007, s. 35), formalismus na školách souvisí také s výkladem tématu: "Hledáni modelového čtenáře je jednou z takových radikálních potřeb člověka a je proto pod tordou veřejnou kontrolou. Ve škole se po nás vyžaduje, čtení schválené uznávanými autoritami', a to znamená, že čtenári aspirující na ,pochopení textu' musí akceptovat určité režimy četby a výkladu přečteného, jinak bude jejich čtení považováno za nevědecké, nerozumějicí či podvratné."

Jaká je souvislost mezi formalismem pasivního čtení a aktivního psaní? Pokud se student ve škole pokouší o aktivní přístup k přečtenému, ale jeho snažení je potlačováno a je mu vnucována akceptace modelového výkladu, může v důsledku tohoto tlaku na aktivní př́istup skutečně rezignovat. Potom u něj existuje vysoká pravděpodobnost ochoty akceptovat mechanický přístupu také k vlastní tvorbě, což je spojeno s rezignací na kreativitu.

\section{Aspekty individuální}

Nyní se konečně dostáváme $\mathrm{k}$ pointě samotného textu, jíž je snaha poukázat na skutečnost, že příčiny plagiátorství spočívají jak v samotné podstatě lidského

\footnotetext{
${ }^{2}$ Ve skutečnosti je použití pojmu plagiát pro doslovný opis poněkud problematické. V současnosti je však pro zmiňované případy používáno zejména v souvislosti s podstatou činu plagiátorství, jímž je vydávání cizí práce za vlastní.
} 
individua, tak také v systémovém nastavení. Pokud jde o příčiny plynoucí z povahy daného člověka, jedná se jednak o již zmiňovanou snahu zjednodušit a ulehčit si práci, avšak nalezneme i další motivy. Do jisté míry se dá říci, že jde také o nedostatek sebevědomí a potřebu opřít se o to, co je osvědčené a obecně akceptované3. Tedy např́klad o to, co již jednou v podobné situaci obstálo. S tím souvisí i zasazení do určité konkrétní situace, která bývá poznamenána určitým tlakem okolí v souvislosti s rodinnou situací, finanční situací či časovými možnostmi.

V jedné z forbín ke hře Těžká Barbora říká Jan Werich: "Daleko víc lidí umí ted'ka psát než před několika málo sty lety. Ono před několika málo sty lety málo lidí umělo psát. Ale ti co uměli psát, ti uměli psát - to se dá číst i ted', to byste nevěríl."

Nadsázka a ironie obsažená ve Werichově výroku se dotýká případů, kdy píší ti, kteří to neumí. Nejedná se pouze o grafomany, ti jsou spíše v menšině. Lidé píší, protože se to po nich chce. Poměr píšících jedinců vưči čtoucím jedincům se za několik posledních desítek let změnil. Více lidí píše, méně lidí čte. Hromadí se tak množství napsaného a není nikdo, kdo by měl čas a chut' napsané číst.

To však směřuje proti smyslu vzdělanosti jako takové. Martin Heidegger se velmi intenzivně zabýval otázkou lidského bytí a jeho autenticity. Neautentické bytí se utápí ve formalismu v okamžiku, kdy věci konáme proto, aby byly „vykonány“ a netážeme se, proč mají být vykonány.

„Otázka sama je cestou. Tato cesta vede od pobytu Řeků až k nám, ne-li dokonce přes nás dál. Setroáme-li u této otázky, jsme na cestě, která má jasný směr. Nemáme tím ovšem ještě zaručeno, že jsme bezprostředně s to po ní náležitě jit. Nemůžeme ani hned posoudit, na kterém místě cesty dnes stojíme. Je odedávna zvykem označovat otázku, co něco je, za otázku po bytnosti. Otázka bytnosti oživne vždy tehdy, když se zatemnilo a popletlo to, čeho bytnost je brána v potaz, a když vztah člověka k tomuto dotazovanému zároveň zakolísal, či byl dokonce otresen." (Heidegger, 1993, 113).

V aspektu intelektuálním tedy běží o klíčovou otázku, je-li plagiát výrazem intelektuální lenosti, nebo zda může být vyjádřením zakolísání (či dokonce otřesení) víry ve smysluplnost psaného díla. Tato otázka nikterak nepodjímá oprávněnost plagiátorství jako takového, avšak může směřovat $\mathrm{k}$ bližšímu popisu jeho př́ičin v okamžiku, kdy svoboda autora je výrazně omezována. Abychom na tomto místě byli konkrétnější, omezování svobody počíná požadavky na v první řadě formální stránku díla - typografii, výrazové prostředky, rozsah, strukturu, na což navazují často i velmi návodné pokyny směřující $\mathrm{k}$ obsahu psaného díla. Tím se vracíme $\mathrm{k}$ závěru předchozí kapitoly. Ještě však lze zmínit další faktor, jímž je autorům

$3 \mathrm{~V}$ př́padě nepřiznané inspirace bývá u plagiátů $\mathrm{v}$ oblasti umění také častým rysem obdiv k původnímu dílu. Tento motiv však nelze akceptovat u prací vědeckých. 
neustále podsouvaná (a opět v principu správná) myšlenka, že čím více toho jedinec prostuduje, tím lepší dílo vytvoří. Na její úskalí upozorňoval již výrazný německý myslitel Arthur Schopenhauer: "Proto se stává, že člověk, který velmi mnoho a téměř celý den čte a mezitím se zotavuje bezmyšlenkovou zábavou, pozvolna ztrácí schopnost sám myslet - jako ten, kdo neustále jezdí na koni, se nakonec odnaučí chodit. A to je také př́pad velice mnoha učenců: čtením zhloupli. Nebot' neustále v každém volném okamžiku hned znovu navázaná četba ochromuje ducha víc než ustavičná ruční práce, protože př̀i té lze ještě sledovat vlastní myšlenky. A stejně jako péro troalým tlakem cizího tělesa nakonec ztrácí pružnost, tak $i$ duch prichází o svou pružnost trvalým tlakem cizích myšlenek." (Schopenhauer, 1994).

Schopenhauer takto vyjadřuje myšlenku, že když čteme, nejsme autentičtí, nebot' za nás myslí někdo jiný. To sice nikoho neospravedlňuje k vydávání cizích myšlenek za vlastní, ovšem sebevědomí autora může být touto ztrátou autenticity výrazně sníženo. Prosté a časté opisování studentů při písemce je ostatně do značné míry také především vyjádřením nedostatku sebevědomí.

\section{Aspekty sociální}

Druhá skupina př́icin vychází ze systémového nastavení. Tedy z požadavků, které jsou na autora práce kladeny, a z konkrétních forem hodnocení práce. Jak ukazují komentáře jinak vesměs seriózních novinářů a publicistů k situaci, jež nastala na FPR ZČU v Plzni, velmi často dochází ke směšování věcí podstatných a nepodstatných a k výrazné preferenci formálních rysů, často vyjádřené přehnaným zdůrazňováním kvantifikace údajů. Počet stran práce či počet položek v seznamu literatury jsou faktory, jež by neměly představovat nejvýznamnější kritérium pro hodnocení kvality práce. Samozřejmě, jedná-li se o př́liš nízká čísla, je práce podežrelá. V extrémních případech jde o práce, jež již z důvodu uvedené nedostatečnosti neměly být obhájeny. To se však spíše týká jiných prací, než těch, které byly označeny za plagiáty. Ostatně doporučený, př́ípadně minimální počet stran, bibliografických odkazů či jiných položek je kritériem naprosto průhledným a případné vybočení se týká tak malého počtu prací, že může být $\mathrm{v}$ daném případě vysvětleno a zdůvodněno. Jinými slovy, pokud úspěšně prošly (at' již z jakýchkoli důvodů) obhajobou práce, které projít neměly z důvodů rozsahu, jde o jiné téma než o plagiátorství.

Přesto však není od věci takovéto případy zmínit. Právě kvůli směšování případů, které sice spojují stejné prostředí a stejná úspěšnost při obhajobě prací, nicméně ve své podstatě jde o případy rozdílné. Práce, jež jsou plagiáty (častěji jsou „jen“ některé jejich části plagiáty), jsou většinou naopak rozsáhlé a splňují formální nároky na obhajobu práce. Citují totiž z toho, co již jednou obhajobou prošlo. Ve hře 
je pochopitelně lidský faktor, ne vždy musí být to, co bylo jednou kvalifikováno jako kvalitní, hodnoceno podruhé stejně, nicméně pravděpodobnost úspěchu je poměrně vysoká.

Snaha o zpřísnění a konkretizaci kritérií pro hodnocení vědeckých prací je v principu chvályhodná a vychází z potřeb vnést systém do nepřehledné situace, jež tu již dlouhá léta panuje. Ovšem, v oblasti měkkých systémů, kde je př́tomen lidský faktor, je každá kvantifikace nutně propojena s důrazem na formální kritéria, jež se pochopitelně mnohem snáze definují a kontrolují. To vede $\mathrm{k}$ byrokratizaci systému. Vědecké konference se mnohdy stávají přehlídkami formálně správně zpracovaných, leč prázdných a nicneříkajících př́spěvků. To platí i pro mnohé články v odborných časopisech, které obsahují hypotézy, tabulky plné čísel, "diskusi“ (která často nemá s diskusí mnoho společného) a jejichž dvojjediným cílem je zapsat si tzv. „čárku“ pro autora a pro vydavatele.

Naposledy ještě ocitujme Václava Bělohradského, který více či méně v této souvislosti hovoří o "akademickém škváru“: „Nazývám tak filosofickou produkci, jež zůstává mimo veřejný prostor, chráněna univerzitní autonomií před závazností rozdilu mezi relevantními a irelevantními instancemi, který se prosazuje ve své dějinotvorné energii jen ve sporech chaotického veřejného prostoru demokratického státu." (Bělohradský, 2007, s. 13).

Prostor pro vlastní myšlenky autora je ořezáván horlivými recenzenty, kteří mají přesně nalinkováno co a jak hodnotit. Systém je nastaven k preferenci uniformizace a chová se hostilně ke všemu, co z jím tvořené uniformity vybočuje. Je naprosto přirozenou reakcí, že mnozí autoři frustrovaní touto hostilitou přistupují na podmínky recenzentů a přepracovávají své př́íspěvky tak dlouho, až jsou přijatelné pro publikování. Určitá (někdy podstatná) část pưvodních myšlenek je tím potlačena. Vždy se najdou jedinci, kteři se dokážou takovéto situaci vzepř́t a budou proti ní bojovat. Vždy se najdou tak výjimeční a schopní autoři, že se prosadí i v „sešněrovaných“ podmínkách. Ovšem těchto jedinců bude vždy jenom menšina. Tím je myšlena menšina nikoli $\mathrm{v}$ rámci běžné populace, nýbrž menšina $\mathrm{v}$ rámci zainteresované části populace. Jde o naprosto přirozený sociální jev. Lidská komunita má vysokou schopnost adaptace na vnější prostředí. To ukazuje př́klad z nedávné minulosti, kdy většina tuzemské populace prokázala schopnost najít si úspěšně svůj životní prostor v podmínkách budování socialismu.

\section{Závěrem}

Je-li nastavení systému takové, že preferuje přesně nalinkovaná schémata, je-li v první řadě hodnoceno dodržování formálních požadavků, dochází u autorů k rezignaci na obsah a na potřebu něco svou prací sdělit. Potom je jejich hlavním motivem prosadit práci v rámci svého kariérního postupu a hledají cestu nejmenšího 
odporu. Takovýto ryze pragmatický či (opět jsme u tohoto slůvka) utilitární přístup je potom „ideálním“ východiskem pro uchýlení se k plagiátorství. Je to cesta rychlá a snadná. Nemá-li autor potřebu předat sdělení, necítí-li se nositelem poselství, může jej od plagiátorství odvrátit bud' pouze hlas svědomí, nebo hrozba odhalení (a s tím spojených komplikací).

Vyhledávání plagiátů a následné represe jsou nutnou a pro určitou skupinu obyvatel nejúčinnější formou boje proti tomuto nešvaru. Nicméně nastavení systému, který by více dbal o smysluplnost vědecké práce, o zvýšení její obsažnosti a snížení formalismu (jenž se projevuje např́klad voblasti tvorby a přijímání projektů a vytváření grantových schémat), by pomohlo konsolidovat takovou atmosféru, v níž by plagiáty nebyly odsuzovány pouze navenek. 


\section{Bibliography}

Anzenbacher, A. Úvod do etiky. Praha: Zvon, 1994. 292 s. ISBN: 80-7113-111-3.

Bayard, P. Le Plagiat par anticipation. Pař́ž: Les Editions de Minuit, 2009. 160 s. ISBN: 9782707320667.

Bednář, M. Pohyb člověka na biodromu. Cesta životem z pohledu (nejen) kinantropologie. Praha: Karolinum, 2009. 190 s. ISBN: 978-80-246-1665-0.

Bělohradský, V. Společnost nevolnosti. Eseje z pozdější doby. Praha: Sociologické nakladatelství, 2007. 301 s. ISBN: 978-80-86429-80-9.

Blecha, I. Filosofie (základní problémy). Olomouc: Fin, 1996. 271 s. ISBN: 80-7182-0326.

Čapek, J. O povinnosti člověka vůči sobě samému: Patočka, Kant a Charta 77. In Filosofický časopis, 2009, 57, č. 4, s. 491 -506. ISSN: 0015-1831.

Heidegger, M. Básnicky bydli člověk. Praha: OIKOYMENH, 1993. ISBN: 80-8524140-4.

Hrbek, M. "Smrt Boha" v Nietzscheho filosofii. Praha: Academia, 1997. 221 s. ISBN: 80-200-0588-9.

Jirásek, I., Frömmel, K. Nedodržování publikační etiky jako výraz „intelektuální lenosti“. In Česká kinantropologie, 2005, 9, č. 2, s. 43-48. ISSN: 1211-9261.

Kant, I. Základy metafyziky mravư. Praha: Svoboda, 1990. 129 s. ISBN: 80-205-0152-5.

Nietzsche, F. Ecce homo. Olomouc: J. W. Hill, 2001. 133 s. ISBN: 80-86427-13-7.

Nietzsche, F. Soumrak model. Praha: Votobia, 1995. 195 s. ISBN: 80-85885-33-6.

Patočka, J. Kaciřské eseje o filosofii dějin. Praha: Academia, 1990. 162 s. ISBN: 80-2000269-4.

Platon. Faidros. Praha: Československý spisovatel, 1958. 81 s.

Schopenhauer, A. O spisovatelství a stylu. Praha: Hynek, 1994. ISBN: 80-85906-00-7.

Špecián, P. Proměny přirozeného světa. Husserl, Patočka a dál? In E-LOGOS, 2009, 12, s. 1-23. ISSN: 1211-0442. 
Voskovec, J., Werich, J. Hry Osvobozeného divadla. Praha: Karolinum, 2000. 633 s. ISBN: 80-8636626-X. 


\section{E-LOGOS}

\section{ELECTRONIC JOURNAL FOR PHILOSOPHY}

Ročník/Year: 2012 (vychází průběžně/ published continuously)

Místo vydání/Place of edition: Praha

ISSN 1211-0442

Vydává/Publisher:

Vysoká škola ekonomická v Praze / University of Economics, Prague

nám. W. Churchilla 4

Czech Republic

13067 Praha 3

IČ: 61384399

Web: http://e-logos.vse.cz

Redakce a technické informace/Editorial staff and technical information:

Miroslav Vacura

vacuram@vse.cz

Redakční rada/Board of editors:

Ladislav Benyovszky (FHS UK Praha, Czech Republic)

Ivan Blecha (FF UP Olomouc, Czech Republic)

Martin Hemelík (VŠP Jihlava, Czech Republic)

Angelo Marocco (Pontifical Athenaeum Regina Apostolorum, Rome, Italy)

Jozef Kelemen (FPF SU Opava, Czech Republic)

Daniel Kroupa (ZU Plzeň, Czech Republic)

Vladimír Kvasnička (FITT STU Bratislava, Slovak Republic)

Jaroslav Novotný (FHS UK Praha, Czech Republic)

Jakub Novotný (VŠP Jihlava, Czech Republic)

Ján Pavlík (editor-in-chief) (VŠE Praha, Czech Republic)

Karel Pstružina (VŠE Praha, Czech Republic)

Miroslav Vacura (executive editor) (VŠEE Praha, Czech Republic) 